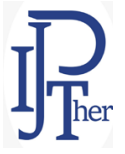

\title{
Indonesian Journal of Pharmacology and Therapy

\section{The liver histopathology structure of Wistar rats on the acute toxicity test of kapulaga (Amomum cardamomum) seeds extract}

\author{
Ratih Dewi Yudhani ${ }^{1,2}$, Rizka Hendriyani ${ }^{3^{*}}$, Riza Novierta Pesik ${ }^{4}$ \\ ${ }^{1}$ Department of Pharmacology, Faculty of Medicine, Universitas Sebelas Maret, Surakarta, \\ ${ }^{2}$ Biomedical Laboratory, Faculty of Medicine, Universitas Sebelas Maret, Surakarta, ${ }^{3}$ Faculty of \\ Medicine, Universitas Sebelas Maret, Surakarta, ${ }^{4}$ Department of Pathology Anatomy, Faculty of \\ Medicine, Universitas Sebelas Maret, Surakarta
}

https://doi.org/10.22146/ijpther.717

Submitted: 18/09/2020

Accepted : 16/12/2020

\section{Keywords:}

cardamom seeds; extract;

the acute toxicity; liver damage;

safety ;

\section{ABSTRACT}

One-third of Indonesian population empirically used herbs for alternative medicine. One of them is kapulaga (Amomum cardamomum) which known as a spice and traditionally used for the treatment of rheumatic, fever, cough, sore throat, and mouth odor. However, its clinical evidences especially its safety are limited. Liver histopathological structure of an acute toxicity test on animal model can demonstrate its safety on human. This study aimed to evaluate histopathological structure of Wistar rats on the acute toxicity test of kapulaga seeds extract. The test was conducted according to the OECD 420 guideline consisting preliminary and main tests. One rat was used in the preliminary test with an initial dose of kapulaga seed extract of 300 $\mathrm{mg} / \mathrm{kgBW}$ and followed by a maximum dose of $2000 \mathrm{mg} / \mathrm{kg} \mathrm{BW}$ after $48 \mathrm{~h}$. Furthermore, 10 rats were used in the main test that randomly divided into control and treatment groups. Regarding the result of the preliminary test, the treatment group was treated with the extract at $2000 \mathrm{mg} / \mathrm{kg}$ BW as a single dose, while the control group was given distilled water. Observations of any toxic signs or dead were conducted every $30 \mathrm{~min}$ in the first $4 \mathrm{~h}$ and continued once per day until $14^{\text {th }}$ day. Assessment of the degree of liver damage was conducted using the liver damaged scoring and compared using the Mann Whitney test. A p value $<0.05$ was considered significant. No significantly different in the liver damage score between control group $(0.96 \pm 0.856)$ and treatment group $(0.96 \pm 0.604)$ was observed $(p>0.05)$. In conclusion, kapulaga seed extract does not has acute toxic effect on the liver of Wistar rats.

\begin{abstract}
ABSTRAK
Sepertiga penduduk Indonesia secara empiris memanfaatkan tanaman untuk pengobatan alternatif. Salah satunya adalah kapulaga (Amomum cardamomum) yang dikenal sebagai rempah-rempah dan secara tradisional digunakan untuk pengobatan rematik, demam, batuk, sakit tenggorokan, dan bau mulut. Namun demikian, bukti klinik kapulaga khususnya keamanannya masih terbatas. Gambaran histopatologi hepar pada uji toksisitas pada hewan model dapat menggambarkan keamanan pada manusia. Penelitian ini bertujuan mengevaluasi gambaran histopatologi tikus Wistas pada uji toksisitas akut ekstrak biji kapulaga. Uji dilakukan menurut petunjuk OECD 420 yang terdiri uji pendahuluan dan uji utama. Seekor tikus digunakan dalam uji pendahuluan dengan dosis awal $300 \mathrm{mg} / \mathrm{kg}$ BB ekstrak biji kapulaga dan diikuti dosis maksimum $2000 \mathrm{mg} / \mathrm{kg}$ BB setelah 48 jam. Selanjutnya, pada uji utama digunakan 10 ekor tikus yang dibagi secara random menjadi kelompok perlakuan dan kelompok kontrol. Dari hasil uji pendahuluan, kelompok perlakuan diberi ekstrak dosis $2000 \mathrm{mg} / \mathrm{kg}$ BB, sedangkan kelompok control diberi akuades. Pengamatan gejala toksisitas dan kematian hewan uji dilakukan setiap 30 menit pada 4 jam pertama dan dilanjutkan satu kali per hari hingga hari ke14. Penilaian derajat kerusakan hepar dengan skoring derajat kerusakan hepar untuk selanjutnya dibandingkan antar kelompok menggunakan uji Mann Whitney. Nilai $p<0,05$ dianggap berbeda bermakna. Tidak terdapat perbedaan nyata dalam skor derajad kerusakan hepar antara kelompok control $(0,96 \pm 0,856)$ dan kelompok perlakuan $(0,96 \pm 0,604)(p>0,05)$. Dapat disimpulkan, ekstrak biji kapulaga tidak mempunyai efek toksik akut pada hepar tikus Wistar.
\end{abstract}

*corresponding author: hendriyanirizka@gmail.com 


\section{INTRODUCTION}

Medicinal plants have been used traditionally for the treatment of various illness for a long time. The World Health Organization (WHO) estimated that around $80 \%$ of the world's population uses herbal plants to support their healthcare. ${ }^{1}$ According to SUSENAS / Survei Sosial Ekonomi Nasional (National Socioeconomic Survey) in 2017, ${ }^{2}$ more than one-third of Indonesian population use empirically medicinal as alternative medicine. This is based on belief that herbal plants have beneficial effects to cure certain diseases.

One of the plants that popular in community as herbal remedies is kapulaga or cardamom (Amomum cardamomum). ${ }^{3}$ The kapulaga seeds are the most popular part of the plant that often used as a food flavoring or a traditional remedy in the community. ${ }^{4}$ In Indonesia, kapulaga is commonly used as a spice and food freshener. Moreover, it has other pharmacological properties such as relieving rheumatic, reducing fever, curing sore throat, cough, stomach pain, and reducing mouth odor. ${ }^{5}$ Winarsi et al. ${ }^{6}$ showed that kapulogo leaf extract can reduce blood glucose levels so it is potential to develop as an antidiabetic agent. This study also reported that the kapulaga leaf extract could be useful as antiatherogenic and antiobesity. ${ }^{6}$ Other study using agar well diffusion method by Singh et al. ${ }^{7}$ revealed that the essential oil of Elletaria cardamom at 3000 ppm has antibacterial activities against many bacteria such as Stapylococcusaureus, Bacillus cereus, Escherichia coli and Salmonella typhi.

Some of those evidences, showed the potential of kapulaga to develop as an herbal medicine. However, for its use in clinical setting, its safety evidence should be investigated. The National Agency of Food and Drug Control of Republic of Indonesia recommended toxicological test on animal model for a substance before used in humans. ${ }^{8}$ Some toxicology studies have been recommended such as the acute toxicity test, sub-chronic toxicity test and chronic toxicity test. $^{9}$ Acute toxicity test is one of the pre-clinical study designed to investigate the toxic effect of a compound in short time during 24 $\mathrm{h}$ after a single dose of administration. The procedure of the acute toxicity testing can be performed base on OECD (Organization for Economic Cooperation and Development) Guidelines for testing Chemical. ${ }^{10}$ In this guidelines, histopathological structure of the liver is one of the parameters which can be used to evaluate the toxic effect of the compound. It is well known that the liver is the most important organ for the detoxification of any compound. Therefore, xenobiotics and drug-induced liver toxicity is becoming the main reason for the withdrawal of an approved the xenobiotics or drugs. ${ }^{11,12}$

Acute toxicity study of kapulaga on the renal function of rats was reported by Yudhani et al. ${ }^{13}$ It was reported that kapulaga does not affect both ureum and creatinine levels of rats demonstrating no toxic effect on renal function. In this study, the acute toxicity of kapulaga seeds (A. cardamomum) extract based on the liver histopathological structure of Wistar rats was reported.

\section{MATERIALS AND METHODS}

\section{Extract preparation}

The kapulaga seed was obtained from Kulon Progo District, Yogyakarta Special Region. Extract was prepared by maceration methods at the Biology Pharmacy Laboratory, Faculty of Pharmacy, Universitas Gadjah Mada, Yogyakarta. The kapulaga seeds were grounded and powdered. The powder was then macerated with $70 \%$ ethanol solvent for $48 \mathrm{~h}$. The solvent was separated from the residual kapulaga powder by filtration using Wharman filter paper. The solvent was then evaporated using a rotatory to obtaindry extract. 


\section{Animal housing}

Wistar female strain rats aged 8-12 weeks old with 120-180 body weight (BW), physically health, not pregnant, and not previously used were used in this study. Rats were obtained from the Integrated Research and Testing Laboratory (Laboratorium Penelitian dan Pengujian Terpadu), Universitas Gadjah Mada, Yogyakarta. Two weeks prior to the acute toxicity study, all rats were acclimatized in standard laboratory conditions. Rats were housed in the individual plastic cages at temperature of $22-24{ }^{\circ} \mathrm{C}, 12 \mathrm{~h}$ dark-light cycle and relative humidity. They were feed with standard food and water were given ad libitum. The rats were handled in accordance with the standard guidelines for the care and use of laboratory animals (CPCSEA guidelines). Protocol of this study was approved by the Health Research Ethics Committee, Faculty of Midicine, Universitas Sebelas Maret/Dr. Moewardi General Hospital, Surakarta (ref. No. 624/VI/HREC/2017).

\section{Acute toxicity testing}

The acute oral toxicity study was conducted according to OECD Test Guideline 420 Acute Oral Toxicity-Fixed Dose consisting of preliminary test and main test. Ten hours (20.00 p.m - 06.00 a.m) prior to study, rats were fasted from any food and followed by fasting from any food and water for $2 \mathrm{~h}(06.00$ -08.00 a.m) prio to the study. This acute toxicity study began with a preliminary test involving 1 rat that was given oraaly kapulaga seed extract $300 \mathrm{mg} / \mathrm{kg}$ BW as the initial dose. At this initial dose, there neither any toxicity nor death of the animal test, therefore the dose was increased to $2000 \mathrm{mg} / \mathrm{kg}$ BW which was given orally as a single dose, $48 \mathrm{~h}$ after treatment with initial dose.The toxicity study was continued with the main test involving a total of 10 rats which were divided into two groups, the control and treatment groups. Treatment group rats were given orally a single dose of kapulaga seed extract of $2000 \mathrm{mg} / \mathrm{kg}$ BW, while control rats were given only distilled water. Observations of any toxic signs or dead were conducted every $30 \mathrm{~min}$ in the first $4 \mathrm{~h}$, continued with observation once day until the $14^{\text {th }}$ day and followed by termination. The rat liver tissues of both group were stain using hematoxylin eosin (HE) procedure for hepatological examination.

\section{Histological examination}

The observation of the liver histopathological structure was conducted in 10 fields of view using a light microscope with 10x40 magnification to assess fat degeneration and necrosis, whilst $10 \times 10$ magnification to assess acini dilation. The degree of liver damage assessment was performed using the scoring for the degree of liver damage (TABLE 1$).{ }^{14}$

TABLE 1. Scoring for the degree of liver damaged. ${ }^{14}$

\begin{tabular}{cl}
\hline Score & \\
\hline 0 & Normal hepatocytes \\
1 & The acinus dilation, fatty degeneration or focused necrosis in one place \\
2 & The acinus dilation, fatty degeneration or focused necrosis in several places \\
3 & $\begin{array}{l}\text { The acinus dilation, fatty degeneration or focused necrosis in the whole liver } \\
\text { tissues }\end{array}$ \\
\hline
\end{tabular}




\section{Statistical analysis}

The mean score of the liver damaged in both groups were presented as mean \pm standard deviation (SD). The Shapiro-Wilk test used to assess the data normality's and followed by Mann Whitney test to analyze the statistical differences of the liver damaged between treatment and control group. A pvalue 0.05 or less was considered as statistically significant.

\section{RESULTS}

The liver histopathological structure and the measurement of acini length after the acute toxicity test of kapulaga seeds extract of the control and treatment groups are shown in FIGUREs 1 and 2. The liver histopathological structure were assessed based on the scoring of the degree of liver damage in TABLE $1 .^{14}$ The score of the degree of liver damage

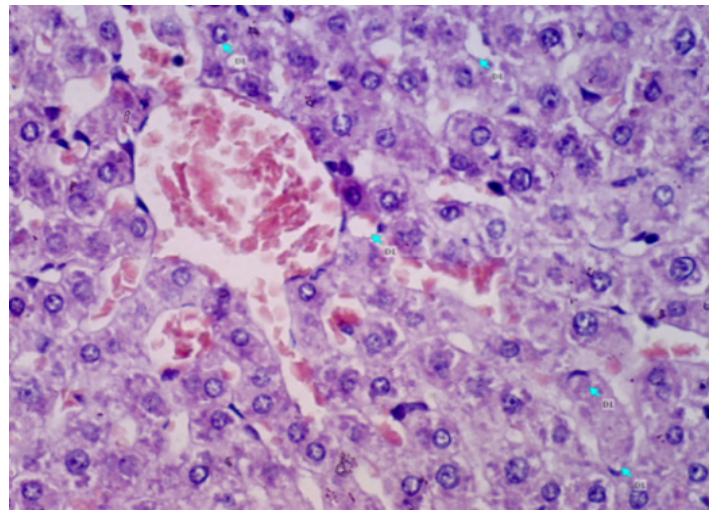

(a) of the control and the treatment group are shown in FIGURE 3.

FIGURE 1 showed that the liver histopathology structure of both groups still normal. This can be seen from the hepatocytes which normal arranged radially from the edge of the lobule to the central vein. ${ }^{15}$ Theacini length of the liver tissue between the treatment and control groups also did not change significantly (FIGURE 2).

The mean score of the liver damage in the control group and treatment group were $0.96 \pm 0.856$ and $0.96 \pm 0.604$, respectively(FIGURE 3). Shapiro Wilk test showed that this data was not normally distributed ( $p<0.05)$. Hence, the mean score of the liver damage in both groups was analyzed using the Mann Whitney test. The results showed that there was no any statistically differences on the mean of liver damage score of both groups $(\mathrm{p}=0.858)$.

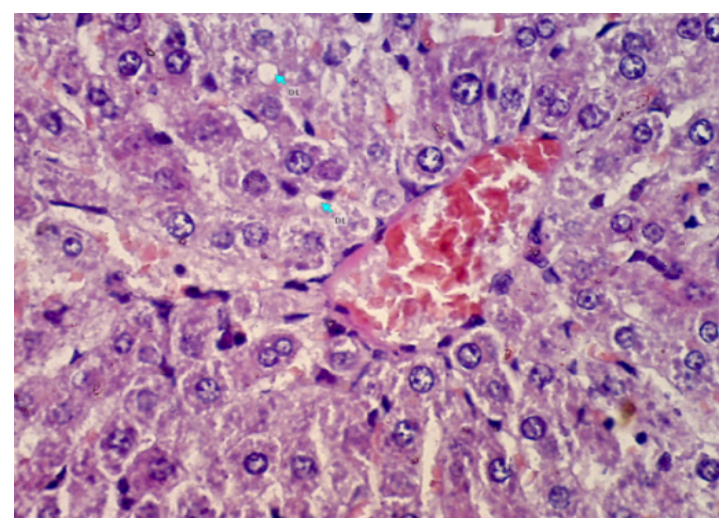

(b)

FIGURE 1. Liver histopathological structure of rat in control group (a) and treatment group (b)(magnification 10x40)

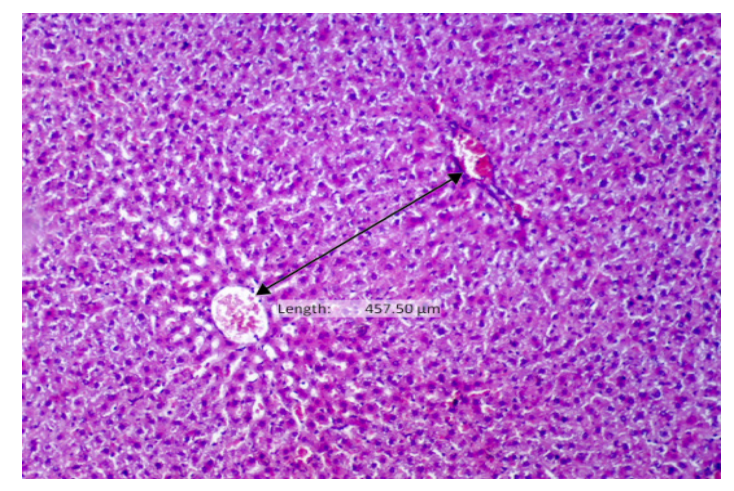

(a)

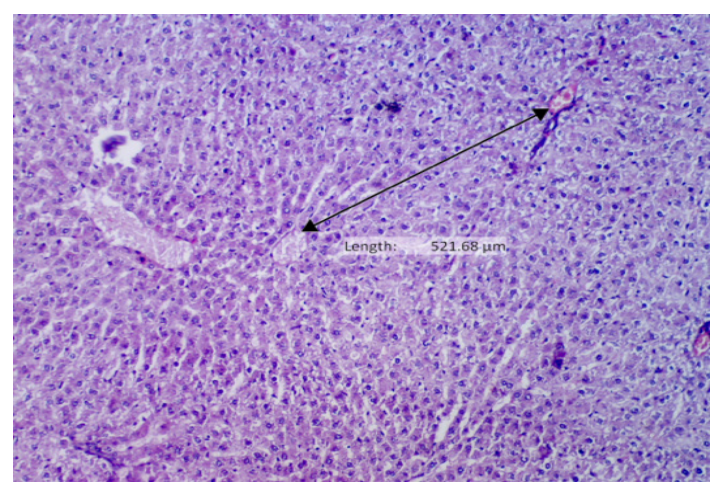

(b)

FIGURE 2. The measurement of rat's acinus length at control group (a) and treatment group (b) (magnification 10x10). 


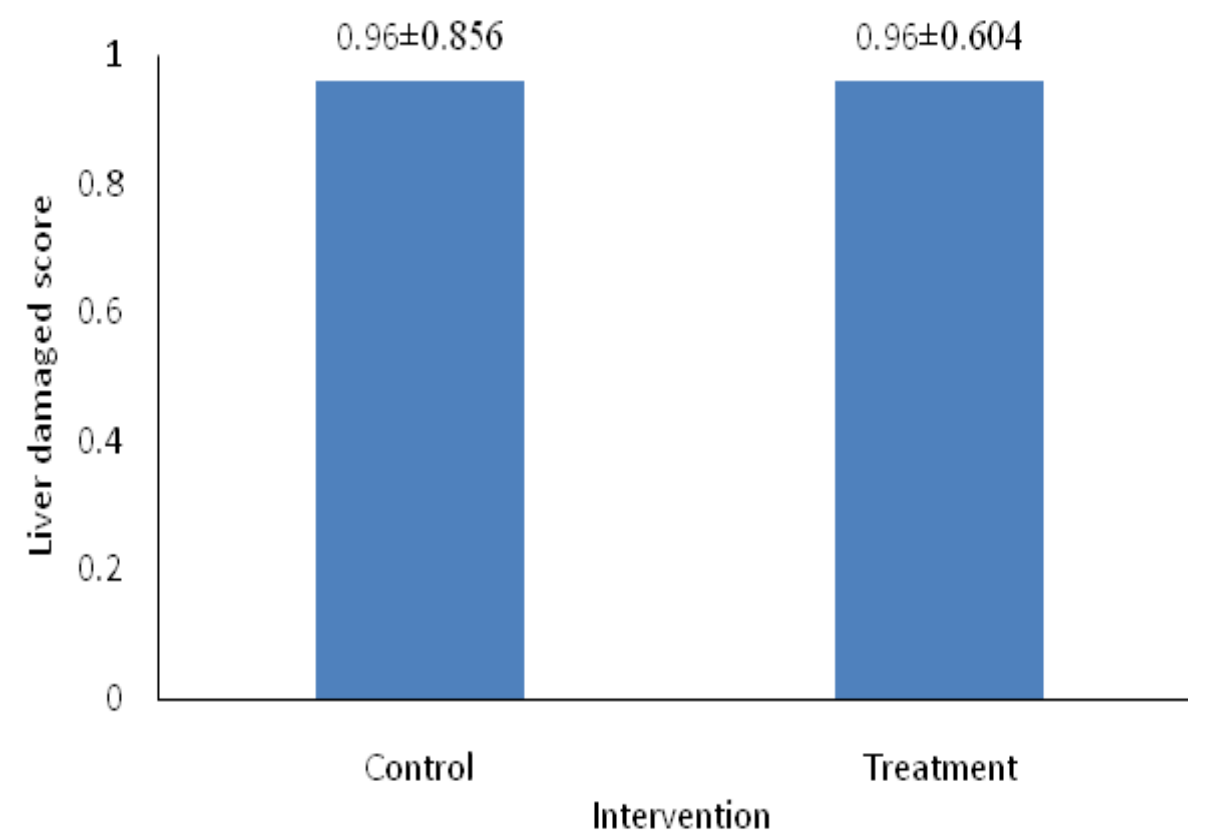

FIGURE 3. The degree of liver damaged between control and treatment

\section{DISCUSSION}

Liver histophatological structures (FIGURE 1) and the acinus length (FIGURE 2) of both groups were similar and still in normal structure. The scoring of liver damaged also similar in both group which closed to score 1 (FIGURE 3). It due to there were minimally found of acinus dilation in both groups. Panqueva ${ }^{16}$ reported that the histopathological pattern of acute hepatocellular damaged if there were the finding of hepatocellular compromise with necrosis and ballooning degeneration in entire acini. Those indicated that a single dose of kapulaga (2000 mg/kg BW) was not toxic based on the liver histopathological parameter. It did not alter the normally arrangement of liver histopathological structure.

The acute toxicity test of kapulaga seed extractat maximum dose $(2000 \mathrm{mg} /$ $\mathrm{kg} \mathrm{BW}$ ) had no effect on the liver, possibly because kapulaga has a hepatoprotective effect. The phytochemicals of Cardamom seed contain various kind of antioxidants such as phenolic and flavonoids. ${ }^{17,18}$ The antioxidant properties possessed by flavonoids through the inhibition of oxidation reactions. This can prevent oxidative stress and block the formation of reactive oxygen species (ROS), hence prevent cell damage, especially in liver cells. ${ }^{19}$

Moreover, ethyl acetate fraction derived from Amomum cardamomum (EAAC) can reduce the liver damage caused by acute induction of $\mathrm{CCl}_{4}$. This is based on its ability to decrease the GOT (glutamic oxaloacetic transaminase), GPT (glutamic pyruvate transaminase) and ALP (alkaline phosphatase) in the treatment group compared to the control. This ability is mediated by the flavonoid and polyphenolsrich content in the EACC. ${ }^{4}$

Rahman et al., ${ }^{20}$ proved that the supplementation of cardamom powder in high carbohydrate high fat diet (HCHF) rats could normalized the liver histological structure due to its several abilities to prevent the infiltration of inflammatory cells and fat deposition. It also reduced the extracellular matrix accumulation and liver fibrosis induced by HCHF diet. Moreover, cardamom restored the liver function through its effect on decreasing the ALT, AST and ALP plasma level. ${ }^{20}$ 
In line with this acute toxicity study, the collecting evidence which mentioned before, supported the hepatoprotective properties of kapulaga (A.cardamomum). Whereas, this study has limitations because it only observes the acute toxic effects of kapulaga seeds extract without continuing to explore the subchronic and chronic toxic effects of this extract. Comprehensive study of kapulaga seed extract toxicity, i.e, acute, subchronic and chronic toxicity with various parameters (toxicity signs, biochemical and histopatological structure of liver and renal, biochemical of other vital organ) needed to support the use of kapulaga seeds in the clinical setting.

\section{CONCLUSION}

Kapulaga seeds (A. cardamomum) does not affect the liver histopathological structure of Wistar rats on the acute toxicity testing.

\section{REFERENCES}

1. Radji M. Peranan bioteknologi dan mikroba endofit dalam pengembangan obat herbal.Majalah Ilmu Kefarmasian 2005; 3: 113-126.

2. Word Health Organization. The Republic of Indonesia health system review. 2017;7:168.

3. Pusat Studi Biofarmaka. Pasar domestik dan ekspor produktanaman obat (Biofarmaka). obtrando. Available from: wordpress.com/ pasar-domestik-dan-ekspor-produktanobatbiofarmaka.pdf. 2009.

4. Lim DW, Kim H, Park JY, Kim JE, Moon JY, Park SD,et al. Amomum cardamomum L. ethyl acetate fraction protects against carbon tetrachloride-induced liver injury via an antioxidant mechanism in rats. BMC Complement Altern Med 2016; 16(155):1-10.

https://doi.org/10.1186/s12906-016-1121-1

5. Sinaga E. Amomum cardamomum Wild (Kapulaga). Pusat Penelitian dan Pengembangan Tumbuhan Obat UNAS. http://www.warintek.ristek.go.id/ pangan_kesehatan/tanaman_obat/ depkes/Kapulaga.pdf. 2008.

6. Winarsi H, Sasongko N D, Purwanto A, Nuraeni I. Ekstrak daun kapulaga menurunkan indeks atherogenik dan kadar gula darah tikus diabetes induksi alloxan Agritech 2013; 33(3):273-80.

https://doi.org/10.22146/agritech.9548

7. Singh G, Kiran S, Marimuthu P, Isidorov V, Vinogorova V. Antioxidant and antimicrobial activities of essential oil and various oleoresins of Elettaria cardamomum(seeds and pods). J Sci Food Agric 2008; 88:280-9.

8. Badan Pengawas Obat dan Makanan (BPOM). Pedoman uji toksisitas nonklinik secara in vivo. 2014. Jakarta: BPOM Republik Indonesia.

9. Gunawan AG, Setiabudy R, Nafrialdi, Elysabeth (ed). Farmakologi dan terapi. Edisi ke 5. Jakarta: Departemen Farmakologi dan Terapeutik Fakultas Kedokteran Universitas Indonesia 2012; 824:8-9.

10. OECD (Organisation for Economic Cooperation and Development). OECD Guidelines for Testing of Chemicals. Test No. 420: Acute oral toxicity: fixed dose prosedure. Paris: OECD, 2001; pp:1-6.

11. Paul S, Islam A, Tanvir EM, Ahmed R, Das S, Rumpa NES, et al. Satkara (Citrus macroptera) fruit protects against acetaminophen-induced hepatorenal toxicity in rats. Evid Based Compl Alt 2016: 1-11. https://doi.org/10.1155/2016/9470954

12. Babai S, Auclert L, Le-Louet H. Safety data and withdrawal of hepatotoxic drugs. Therapie 2017; 251:1-3.

h t t p s://d oi .org/10.1016/j . therap.2018.02.004

13. Yudhani RD, Pesik RN, Azzahro S, Anisa AF, Hendriyani R. Renal function parameter on acute toxicity test of kapulaga (Amomum cardamom) seed extract in rat. IOP Conf Ser Mater Sci Eng 2019; 578(012053):1-6.

https://doi.org/10.1088/1757899X/578/1/012053 
14. Andreas $H$, Trianto HF, Ilmiawan MI. Gambaran histologi regenerasi hati pasca penghentian pajanan monosodium glutamat pada tikus wistar. E-Jurnal Kedokteran Indonesia 2015; 3(1):2.

15. Mescher AL. Junqueira's basic histology text and atlas. $14^{\text {th }}$ ed. New York: McGraw Hill Education 2016; p:335.

16. Panqueva RCDPL. Morphological issues of drug induced liver disease. Rev Col Gastroenterol 2014; 29(4):439-50.

17. Sultana S, Ripa FA, Hamid K. Comparative antioxidant activity study of some commonly used spices in Bangladesh. Pakistan J Biol Sci 2010; 1:13(7):340-3.

https://doi.org/10.3923/pjbs.2010.340.343

18. Bhatti HN, Zafar F, Jamal MA.
Evaluation of phenolic contents and antioxidant potential of methanolic extracts of green cardamom (Elettaria cardamomum). Asian J Chem 2010; 22(6):4787-94.

19. Redha A. Flavonoid: struktur, sifat antioksidatif dan peranannya dalam sistem biologis. Jurnal Belian 2010; 9(2):196-202.

20. Rahman M, Alam MN, Ulla A, Sumi FA, Subhan N, Khan T, et al. Cardamom powder supplementation prevents obesity, improves glucose intolerance, inflammation and oxidative stress in liver of high carbohydrate high fat diet induced obese rats. Lipids Health Dis 2017; 16(151):1-12. https://dx.doi.org/10.1186\%2Fs12944017-0539-X 